\title{
Research Article \\ INTEGRATED NUTRIENT MANAGEMENT IN DILL (Anethum sowa Roxb)
}

\author{
SINGH PRADIP1, NARUKA I.S. ${ }^{2}$, SHAKTRAWAT R.P.S. ${ }^{3 *}$, SINGH O.P. ${ }^{4}$, GALLANI R. ${ }^{5}$ AND PATIDAR D. K. ${ }^{6}$ \\ 1,2,6Department of Plantation, Spices, Medicinal and Aromatic Crops, KNK College of Horticulture, Mandsaur, Madhya Pradesh 458001, India \\ 3Department of Agronomy, KNK College of Horticulture, Mandsaur, Madhya Pradesh 458001, India \\ 4Department of Plant Physiology, KNK College of Horticulture, Mandsaur, Madhya Pradesh 458001, India \\ ${ }^{5}$ Department of Soil Science, KNK College of Horticulture, Mandsaur, Madhya Pradesh 458001, India \\ *Corresponding Author: Email-rpssbkn@yahoo.co.in
}

Received: February 06, 2018; Revised: February 12, 2018; Accepted: February 13, 2018; Published: February 15, 2018

\begin{abstract}
A field experiment was conducted during the Rabi season of 2016-17 at Horticultural experimental farm, College of Horticulture Mandsaur to study the effect of integrated nutrient management on growth, yield and quality of dill (Anethum sowa Roxb). The eight treatment combinations of different fertilizers doses, vermicompost and biofertilizers were tested in randomized block design with three replications. Integrated nutrient management significantly influenced different growth, yield and quality parameters of dill. Application of treatment $100 \% \mathrm{NPK}+5$ tons Vermi-compost/ha + PSB $5 \mathrm{~kg} / \mathrm{ha}$ and Azotobacter $5 \mathrm{~kg} / \mathrm{ha}$ gave significant maximum plant height $(168.1 \mathrm{~cm})$, branches plant ${ }^{-1}(45.8)$, fresh weight of plant $\left(336.1 \mathrm{~g} \mathrm{plant}^{-1}\right)$, dry weight of plant $\left(109.3 \mathrm{~g} \mathrm{plant}^{-1}\right)$, umbel plant-1 $(99.6)$, umbelletumbel-1 $(34.0)$, seed umnellet-1(22.4), seed umbel-1 $(745.2)$, seed yield $\left(17.50 \mathrm{q} \mathrm{ha}^{-1}\right)$, straw yield $\left(29.00 \mathrm{q} \mathrm{ha}^{-1}\right)$, biological yield (46.50 q ha-1), test weight seed( $(3.87 \mathrm{~g})$ and essential oil content of seed (3.35\%) as compared to all other treatments tested.
\end{abstract}

Keywords- Dill, NPK, Vermi-compost, Azotobacter, PSB.

Citation: Singh Pradip, et al., (2018) Integrated Nutrient Management in Dill (Anethum sowa Roxb.). International Journal of Agriculture Sciences, ISSN: 0975-3710 \& EISSN: 0975-9107, Volume 10, Issue 3, pp.-5134-5136. DOl: http://dx.doi.org/10.9735/0975-3710.10.3.5134-5136

Copyright: Copyright@2018 Singh Pradip., et al., This is an open-access article distributed under the terms of the Creative Commons Attribution License, which permits unrestricted use, distribution and reproduction in any medium, provided the original author and source are credited.

Academic Editor / Reviewer: Dr Al-kazafy Hassan Sabry, Dr Eleonora Nistor

\section{Introduction}

Dill is one of an annual aromatic and medicinal plant belonging to the apiaceae family. There are two species of dill under cultivation i.e. European dill (Anethum graveolens L.) and another closely related is Indian dill (Anethum sowa Roxb). Sowa is an annual, glabrous, branches winter annual herb, growing up to $1.2 \mathrm{~m}$ height. Dill seed and leaves are used as flavouring in sauces vinegars, pastries and soups. Dill seed has medicinal value as a diuretic, stimulants and a carminative. The dill seed have essential oil as an active substance, while carvone and limonene are the main constituents of essential oil. The emulsion of dill oil in water is considered to be carminative, anti-flatulent, anti-colic pain, anti-vomiting and anti-hiccups for infant and children [1]. The gripe water is prepared from its seed, which is used to improve digestion and control vomiting in infants. In India dill seed is cultivated in about 36 thousand hectares with production of about 35 thousand metric tonnes [2]. It is cultivated commercially in Rajasthan, Gujarat, Maharashtra, Andhra Pradesh and Madhya Pradesh states of India. The productivity of dill is very low due to imbalance use of nutrients through fertilizer only. Vermicompost are finely divided peat-like materials with high porosity, aeration, drainage and water holding capacity and usually contain most nutrients in the available forms such as nitrates, phosphates and soluble potassium [3, 4]. Similarly, bio-fertilizers like Azotobacter spp. and Azospirillium spp. help in improving soil fertility through biological nitrogen fixation, solubilising phosphorus from native soil and applied source and mobilizing the micro-nutrients for plant uptake [5]. Chemical fertilizers play an important role to meet nutrient requirement of the crop but their continuous indiscriminate and improper use on lands will have deleterious effects on physical, chemical and biological properties of soil, which in turn reflects on yield [6]. Keeping all these in mind, an experiment entitled integrated nutrient management on growth, yield and quality of dill (Anethum sowa Roxb) was conducted.

\section{Materials and Methods}

The field experiment was conducted during Rabi season of 2016-17 at the research farm, RVSKVV, College of Horticulture, Mandsaur (Madhya Pradesh) on light black loamy soil having pH 7.7, EC $0.64 \mathrm{dS} / \mathrm{m}, 227 \mathrm{~kg}$ available nitrogen ha-1, $15.56 \mathrm{~kg}$ available phosphorus ha-1 and $403 \mathrm{~kg}$ available potassium ha-1. The experiment was conducted in Randomized Block Design with three replications. There were 8 treatments in the experiment viz.,100\% NPK(80:60:40 kg/ha), 100\% $\mathrm{NPK}+2.5$ tons Vermi-compost/ha + PSB $5 \mathrm{~kg} / \mathrm{ha}+$ Azotobacter $5 \mathrm{~kg} / \mathrm{ha}$, $100 \% \mathrm{NPK}+5$ tons Vermi-compost/ha + PSB $5 \mathrm{~kg} / \mathrm{ha}+$ Azotobacter $5 \mathrm{~kg} / \mathrm{ha}, 75 \%$ $\mathrm{NPK}+2.5$ tons Vermi-compost/ha + PSB $5 \mathrm{~kg} / \mathrm{ha}+$ Azotobacter $5 \mathrm{~kg} / \mathrm{ha}, 75 \% \mathrm{NPK}$ + 5 tons Vermi-compost/ha + PSB $5 \mathrm{~kg} / \mathrm{ha}+$ Azotobacter $5 \mathrm{~kg} / \mathrm{ha}, 50 \% \mathrm{NPK}+2.5$ tons Vermi-compost/ha + PSB $5 \mathrm{~kg} / \mathrm{ha}+$ Azotobacter $5 \mathrm{~kg} / \mathrm{ha}, 50 \% \mathrm{NPK}+5$ tons Vermi-compost/ ha + PSB $5 \mathrm{~kg} / \mathrm{ha}+$ Azotobacter $5 \mathrm{~kg} / \mathrm{ha}, 5$ tons Vermicompost/ha + PSB $5 \mathrm{~kg} / \mathrm{ha}+$ Azotobacter $5 \mathrm{~kg} / \mathrm{ha}$. The dill cv. NRCSS AD-2 was sown in plots. Treatments were applied in the form of urea, SSP, MOP, Vermicompost, PSB and Azotobacter. The seeds were sown at the rate of $4 \mathrm{~kg} / \mathrm{ha}$. Weeding was done at 30and 60 DAS manually. To test the significance of variation in the data obtained, the analysis of variance technique for RBD was adopted as suggested by Pansey and Sukhatme, (1984) [7].

\section{Result and Discussion \\ Growth attributes \\ Application of $100 \% \mathrm{NPK}+5$ tons Vermi-compost/ha + PSB $5 \mathrm{~kg} / \mathrm{ha}+$ Azotobacter}


$5 \mathrm{~kg} / \mathrm{ha}$ recorded significant maximum plant height, branches plant ${ }^{-1}$ and days to $50 \%$ flowering. This may be due to the increase of NPK in the root zone and the synergistic effect of the microorganisms on the physiological and metabolic activities of the plant. This enhancing effect may induce exudate of some hormonal substances like cytokinins and auxins, which encourage plant height. The nutrient available in the soil increased with increasing nitrogen application and biofertilizers and thereby the significant effect was observed on growth attributes of dill crop. The increase in growth attributes might be due to the production of more chlorophyll content with the application of fertilizers, vermicompost and also due to production of plant growth regulators by bacteria in rhizosphere, where it is absorbed by roots. These results are in close conformity with the findings of Hussein, et al., (2015) [8] and Valiki, et al., (2015) [9] in fennel and Singh, (2011) [10] in coriander.

\section{Yield attributes and yield}

In the present study, it was observed that NPK, vermin-compost and bio-fertilizers had significant influence on the yield and yield attributes of dill. Application of 100 $\% \mathrm{NPK}+5$ tons vermi-compost/ha + PSB $5 \mathrm{~kg} / \mathrm{ha}+$ Azotobacter $5 \mathrm{~kg} / \mathrm{ha}$ recorded significantly highest fresh weight plant ${ }^{1}(336.1 \mathrm{~g})$, dry weight plant ${ }^{-1}(109.3 \mathrm{~g}$,). number of umbel plant-1 $(99.6)$, number of umbellets umbel-1 $(34.0)$, number of seed umbellets ${ }^{-1}$ (22.4), number of seed umbel-1 (745.2), seed yield (17.50 q ha-1) straw yield ( $29.00 q$ ha $\left.^{-1}\right)$, biological yield ( $46.50 q$ ha $\left.^{-1}\right)$ and harvest index ( 37.63 $\%)$ as compared to rest of the treatments tested. Further, application of $100 \%$ $\mathrm{NPK}+5$ tons Vermi-compost/ha + PSB $5 \mathrm{~kg} / \mathrm{ha}+$ Azotobacter $5 \mathrm{~kg} / \mathrm{ha}$ treatment gave $17.50 \mathrm{q} \mathrm{ha-1}$ seed yield of dill which was 59.09 and 87.16 per cent higher as compared to treatment $100 \%$ NPK (80:60:40 kg/ha) dose (11.00 q/ha) and treatment 5 tons vermi-compost/ha + PSB $5 \mathrm{~kg} / \mathrm{ha}+$ Azotobacter $5 \mathrm{~kg} / \mathrm{ha}$ (9.35 $\mathrm{q} / \mathrm{ha}$ ), respectively.

\begin{tabular}{|c|c|c|c|c|c|c|c|c|}
\hline Treatment & $\begin{array}{l}\text { Plant Height } \\
\text { (cm) }\end{array}$ & $\begin{array}{c}\text { Branches/ } \\
\text { Plant }\end{array}$ & $\begin{array}{c}\text { Fresh } \\
\text { Weight(g) }\end{array}$ & $\begin{array}{l}\text { Dry Weight } \\
\text { (g) }\end{array}$ & $\begin{array}{c}\text { Test } \\
\text { Weight }(g)\end{array}$ & $\begin{array}{c}\text { Essential oil } \\
\text { content of seed (\%) }\end{array}$ & $\begin{array}{l}\text { Days Taken to } \\
\text { Germination }\end{array}$ & $\begin{array}{l}\text { Days to } 50 \% \\
\text { Flowering }\end{array}$ \\
\hline $100 \%$ NPK dose (80:60:40 kg/ha) & 144.4 & 33.8 & 299.2 & 97.6 & 3.49 & 3.23 & 9.0 & 79.7 \\
\hline $\begin{array}{l}100 \% \text { NPK + } 2.5 \text { tons Vermi-compost/ha + } \\
\text { PSB } 5 \mathrm{~kg} / \mathrm{ha}+\text { Azotobacter } 5 \mathrm{~kg} / \mathrm{ha}\end{array}$ & 155.2 & 40.1 & 308.3 & 100.4 & 3.74 & 3.31 & 8.0 & 82.1 \\
\hline $\begin{array}{l}100 \%+5 \text { tons Vermi-compost/ha + PSB } 5 \\
\mathrm{~kg} / \mathrm{ha}+\text { Azotobacter } 5 \mathrm{~kg} / \mathrm{ha}\end{array}$ & 168.1 & 45.8 & 336.1 & 109.3 & 3.87 & 3.35 & 8.0 & 86.0 \\
\hline $\begin{array}{l}75 \% \text { NPK + } 2.5 \text { tons Vermi-compost/ha + } \\
\text { PSB } 5 \mathrm{~kg} / \mathrm{ha}+\text { Azotobacter } 5 \mathrm{~kg} / \mathrm{ha}\end{array}$ & 149.0 & 37.5 & 302.0 & 99.1 & 3.53 & 3.24 & 8.7 & 80.7 \\
\hline $\begin{array}{l}75 \% \text { NPK + } 5 \text { tons Vermi-compost/ha + PSB } \\
5 \mathrm{~kg} / \mathrm{ha}+\text { Azotobacter } 5 \mathrm{~kg} / \mathrm{ha}\end{array}$ & 151.3 & 37.7 & 305.7 & 99.4 & 3.58 & 3.29 & 8.7 & 81.5 \\
\hline $\begin{array}{l}50 \% \text { NPK + } 2.5 \text { tons Vermi-compost/ha + } \\
\text { PSB } 5 \mathrm{~kg} / \mathrm{ha}+\text { Azotobacter5 kg/ha }\end{array}$ & 116.7 & 30.8 & 289.5 & 95.5 & 3.08 & 2.79 & 9.7 & 78.1 \\
\hline $\begin{array}{l}50 \% \text { NPK + } 5 \text { tons Vermi-compost } / \mathrm{ha}+\text { PSB } \\
5 \mathrm{~kg} / \mathrm{ha}+\text { Azotobacter } 5 \mathrm{~kg} / \mathrm{ha}\end{array}$ & 129.4 & 32.5 & 296.6 & 97.9 & 3.43 & 3.18 & 9.7 & 79.0 \\
\hline $\begin{array}{l}5 \text { tons Vermi-compostha + PSB } 5 \mathrm{~kg} / \mathrm{ha}+ \\
\text { Azotobacter } 5 \mathrm{~kg} / \mathrm{ha}\end{array}$ & 100.7 & 25.2 & 262.0 & 86.0 & 3.06 & 2.75 & 9.7 & 74.0 \\
\hline S.Em. \pm & 4.11 & 1.65 & 9.03 & 2.86 & 0.038 & 0.009 & 0.56 & 1.07 \\
\hline $\mathrm{CD}$ at $5 \%$ & 12.47 & 5.00 & 27.38 & 8.68 & 0.114 & 0.026 & NS & 3.26 \\
\hline
\end{tabular}

\begin{tabular}{|c|c|c|c|c|c|c|c|c|}
\hline Treatment & $\begin{array}{l}\text { Umbel } \\
\text { IPlant }\end{array}$ & $\begin{array}{c}\text { Umbellet / } \\
\text { Umbel }\end{array}$ & $\begin{array}{l}\text { Seed / } \\
\text { Umbellet }\end{array}$ & $\begin{array}{c}\text { Seed } \\
\text { /Umbel } \\
\end{array}$ & $\begin{array}{l}\text { Seed Yield } \\
(\mathrm{q} / \mathrm{ha})\end{array}$ & $\begin{array}{c}\text { Straw Yield } \\
(\mathrm{q} / \mathrm{ha})\end{array}$ & $\begin{array}{l}\text { Biological Yield } \\
\text { (q/ha) }\end{array}$ & $\begin{array}{c}\text { Harvest } \\
\text { Index (\%) }\end{array}$ \\
\hline $100 \%$ NPK dose (80:60:40 kg/ha) & 75.3 & 27.1 & 20.2 & 535.7 & 11.00 & 20.16 & 31.16 & 35.30 \\
\hline $\begin{array}{l}100 \% \text { NPK + } 2.5 \text { tons Vermi-compost/ha + } \\
\text { PSB } 5 \mathrm{~kg} / \mathrm{ha}+\text { Azotobacter } 5 \mathrm{~kg} / \mathrm{ha}\end{array}$ & 91.3 & 31.4 & 20.4 & 624.8 & 14.15 & 25.77 & 39.92 & 35.45 \\
\hline $\begin{array}{l}100 \%+5 \text { tons Vermi-compost/ha + PSB } 5 \\
\mathrm{~kg} / \mathrm{ha}+\text { Azotobacter } 5 \mathrm{~kg} / \mathrm{ha}\end{array}$ & 99.6 & 34.0 & 22.4 & 745.2 & 17.50 & 29.00 & 46.50 & 37.63 \\
\hline $\begin{array}{l}75 \% \text { NPK + } 2.5 \text { tons Vermi-compost/ha + PSB } \\
5 \mathrm{~kg} / \mathrm{ha}+\text { Azotobacter } 5 \mathrm{~kg} / \mathrm{ha}\end{array}$ & 80.4 & 28.8 & 20.2 & 570.8 & 13.10 & 23.68 & 36.78 & 35.62 \\
\hline $\begin{array}{l}75 \% \text { NPK + } 5 \text { tons Vermi-compost/ha + PSB } \\
5 \mathrm{~kg} / \mathrm{ha}+\text { Azotobacter } 5 \mathrm{~kg} / \mathrm{ha}\end{array}$ & 86.7 & 30.5 & 20.4 & 607.5 & 13.84 & 24.91 & 38.75 & 35.72 \\
\hline $\begin{array}{l}50 \% \text { NPK + } 2.5 \text { tons Vermi-compost/ha + PSB } \\
5 \mathrm{~kg} / \mathrm{ha}+\text { Azotobacter5 kg/ha }\end{array}$ & 63.7 & 20.4 & 18.5 & 362.2 & 10.55 & 19.43 & 29.98 & 35.20 \\
\hline $\begin{array}{l}50 \% \text { NPK + } 5 \text { tons Vermi-compost/ ha + PSB } \\
5 \mathrm{~kg} / \mathrm{ha}+\text { Azotobacter } 5 \mathrm{~kg} / \mathrm{ha}\end{array}$ & 62.2 & 24.0 & 19.8 & 460.9 & 10.70 & 19.66 & 30.36 & 35.24 \\
\hline $\begin{array}{l}5 \text { tons Vermi-composttha + PSB } 5 \mathrm{~kg} / \mathrm{ha}+ \\
\text { Azotobacter } 5 \mathrm{~kg} / \mathrm{ha}\end{array}$ & 54.0 & 17.5 & 15.9 & 264.4 & 9.35 & 17.15 & 26.50 & 35.29 \\
\hline S.Em. \pm & 2.59 & 0.84 & 0.61 & 29.49 & 0.38 & 0.729 & 1.110 & 0.120 \\
\hline CD at $5 \%$ & 7.86 & 2.56 & 1.85 & 89.46 & 1.166 & 2.212 & 3.366 & 0.365 \\
\hline
\end{tabular}

According to Lal, et al., (2012) [11] vermi-compost and bio-fertilizers improves the physical and biological properties of soil including supply of almost all the essential plant nutrient for the growth and development of plant. Thus balance nutrient under favorable environment might have helped in production of new tissue and development of new shoot might have ultimately increased the yield and yield attributes. Application of $100 \% \mathrm{NPK}$, vermi-compost and bio-fertilizers increase the number of seed per umbellets and number of seed per umbel, this might be due to the fact that the plant treated with bio-fertilizers become physiologically more active and enable to synthesize required amount of hormones or to build up adequate food reserves. Integrated use of $100 \%$ NPK, vermin-compost and bio-fertilizers enhances the uptake of $\mathrm{N}, \mathrm{P}$ and $\mathrm{K}$ and also helps in releasing humus forming microbes, nitrogen fixers and some growth regulators which results in the production of more vegetative growth of the plants. Ultimately, these characters had beneficial effect on higher seed yield. These results are in close conformity with the findings of Zahedi and Jahanshahi (2014) [12], Singh and Singh (2016) [13] in dill and Hnamte, et al., (2013) [14] in coriander and Valiki, et al., (2015) [9] in fennel.

\section{Quality attributes}

Application of $100 \%$ NPK +5 tonns vermi-compost/ha + PSB $5 \mathrm{~kg} / \mathrm{ha}+$ Azotobacter $5 \mathrm{~kg} / \mathrm{ha}$ recorded significantly higher test weight and essential oil in seed. This may be due to the improved nutrient availability and improvement in soil nutrient status which provides soil structure, improving root development, providing plant nutrients and enhancing nutrient uptake by plant. Increase of the I 
mineral uptake such as, nitrogen and phosphorus has a positive effect on proper biomass production and subsequently the enhanced seed size and essential oi content. More weight of thousand seed was due to more leaf area for photosynthesis and effective utilization of these photo-synthates from source (leaves) to sink (reproductive parts) which might have resulted in better filling of seeds. These results are in close conformity with the finding of Singh and Singh (2016) [13] in dill and Valiki, et al., (2015) [9] in fennel and Singh, (2011) [10] in coriander.

\section{Conclusion}

On the basis of experiment conducted on integrated nutrient management of dill, it may conclude that application of treatment $100 \%$ NPK +5 tons Vermi-compost/ha + PSB $5 \mathrm{~kg} / \mathrm{ha}$ and Azotobacter $5 \mathrm{~kg} / \mathrm{ha}$ significantly increased different growth, yield and quality parameters as compared to all other treatments tested.

Application of research: The above research work will be applied to improve the physical, chemical and biological properties of soil, which in turn reflects on yield of dill crop.

\section{Research Category: Integrated nutrient management}

Abbreviations: N - Nitrogen, P - Phosphorus, K - Potash, PSB - Phosphorus solubilising bacteria

Acknowledgement / Funding: Authors are thankful to Rajmata Vijayaraje Scindia Krishi Vishwavidyalaya, Gwalior, Madhya Pradesh 474002

\section{*Major Advisor: Dr I. S. Naruka}

University: Rajmata Vijayaraje Scindia Krishi Vishwavidyalaya, Gwalior, Madhya Pradesh 474002

Research project name or number: Nil

Author Contributions: All author equally contributed

Author statement: All authors read, reviewed, agree and approved the final manuscript

Conflict of Interest: None declared

Ethical approval: This article does not contain any studies with human participants or animals performed by any of the authors.

\section{References}

[1] Randhawa G. S. and Singh A. (1988) Indian Perfumer, 32(4), 327-333.

[2] Annonymous (2017) DASD, 2016-17

[3] Atiyeh R.M., Arancon N., Edwards C.A. and Metzger J.D. (2002) Bioresource Technol., 81, 103-08.

[4] Arancon N.Q., Edwards C.A., Bierman P., Metzger J.D. and Lucht C. (2005) Pedobiologia, 49, 297-306.

[5] Chattopadhyay N., Mukherjee A. and Hore J.K. (2017) Journal of Crop and Weed, 13(2), 102-105.

[6] Ramesh P., Singh M. and Rubbarao A. (2005) Current Science, 88(4), 25.

[7] Pansey V.G. and Sukhatme P.V. (1984) ICAR Publication, New Delhi.

[8] Hussein A.H., Said-AL Ahi., Sarhan A.M.Z., Dahab A.D.M.A., Abou-Zeid E.N., Ali M.S. and Naguib N.Y. (2015) International Journal of Life Science and Engineering, 1(2), 75-84. 21.

[9] Valiki S.R.H., Ghanbari S., Golmohammadzadeh S. and Tat O.F. (2015) International Journal of Life Sciences, 9(4), 38-43.

[10] Singh M. (2011) Journal of Spices and Aromatic Crops, 20(1), 30-33.

[11] Lal G., Vashisth T., Mehta R.S. and Ali S.F. (2012) International Journal Seed Spices, 2(1), 1-6.

[12] Zahedi H. and Jahanshahi S. (2014) Biological Forum. An International Journal, 6(2), 357-361.
[13] Singh G. and Singh S. (2016) International Journal of Agricultural Science and Research, 6(3), 2250.

[14] Hnamte V., Chatterjee R. and Tania C. (2013) The Bioscan, 8(3), 791-793. 